\title{
Editorial
}

\section{Theorizing the Social}

According to Leisering in his editorial in this journal, the idea of the "social" not only concerns social services as found in textbooks on social policy, it also "reflects a culturally entrenched notion of the relationship between state and society - a recognition of the tension between the ideal of political equality and socio-economic inequality, and of a collective responsibility by the state for identifying and redressing social problems" (Leisering 2013: 12). Theorizing "social quality" began in Europe at the end of the 1990s, in reaction to the increasing tendency to reduce the European Union's operation to an "economic project." In an ideological sense this reduction was legitimated by decoupling the economic dimension from the socio-political and sociocultural dimensions and leaving the latter two to the authority of the EU member states. The presupposition on the part of neoclassical economics and mainstream political and sociological studies of a duality between "the economic" and "the social" paved the way for this move. Therefore social quality scholars started to theorise 'the social' anew to go beyond the duality of the economic and the social In practice, nation-based policies became subordinated to the European-oriented financial and economic politics and policies that were being used to address the globalization of production and reproduction relationships (Beck et al. 1997). This shift became seriously strengthened by the revolutionary development and application of new communication technologies.

The consequences of the duality and imbalance just described have been highlighted in recent years in "the Greek question," which arose from Greece's refusal to follow the logic of purely financial desiderata. This entrenched, finance-dominated logic has demanded an unbearable amount of unemployment, especially among young people, along with the impoverishment of more than 40 percent of the Greek population (Kougias 2014). At the same time, this logic allows for the untouchable affluence of the upper income groups and for what is essentially a transfer of wealth from poor Greek people to wealthy Northern European bondholding institutions, who have not had to take responsibility for their earlier questionable investments in Greek bonds (Davidson 2015).

In this issue, the Journal explores the tension between economic politics and policies, on the one hand, and the role and meaning of other dimensions of societies on the other hand. As Anna Coote remarks, there are no signs of any sufficient move in this mainstream economics to decouple production from greenhouse emissions by switching to zero-carbon energy sources. Similarly, Gro Harlem Brundtland, who led the famous Report on "Our Common Future" (UN-Commission 1987), observed on the eve of the global conference on sustainability in Rio de Janeiro (in June 2012) that "governments are currently refusing to make the transformative changes needed to 
resolve the global sustainability crisis" (Brundtland 2012). Is this a question of simply "refusing," or are these governments themselves being victimized by the conceptual duality between "the economic" and "the social," which paves the way for uncontrolled financial-economic processes for the accumulation of profit?

Following the Journal's ambition of stimulating a dialogue about various approaches to financial-economic, socio-political, socio-cultural, and environmental challenges, this editorial draws on some important connections raised in the articles gathered here. Raymond Apthorpe's piece, which raises questions about the duality between "the economic" and "the social," serves as the organizational principle for the other articles, which all address aspects of this issue. The economic/social duality is contested in social quality theory, which argues that the economic dimension is an aspect of "the social." (Apthorpe refers to the "social" instead of "the social": is this purely a language difference or does it reflect a theory-based difference?) According to Apthorpe, mainstream economists - and also somewhat heterodox economists like Sen and Stiglitz - do at times permit themselves what he calls "sightings" (or sometimes even lengthier considerations) of what they call "social." He defines "sightings" as "glimpses of what is thought to exist; while 'social' refers to various sorts of notions about 'people." There are various ways of referring to the "social," but they unfortunately add up to little: they consist mainly of a miscellaneous set of "noneconomic" aspects that mainstream "economic" thinking can blame for the "policy performance gap" between what such thinking promises and what it often actually delivers.

The article by Anna Coote has a nineteenth-century ambition, to open new horizons on the basis of new ways of understanding the nature of societies. Referring especially to contemporary British society, she makes a plea for a "new social settlement," or a basic plan for society: it must be an agreement about how people interact with each other economically, socially, and politically. Such an agreement entails interacting in such a way that the planetary boundaries are not crossed. According to Coote, it is the responsibility of social policy to guarantee these safe limits, creating environmental sustainability and, at the same time, "sustainable social justice." Her article presents an overview of recent research, debates, and policies for addressing this aim. This new "social settlement" cannot depend on continuing economic growth or on getting a bigger share of tax revenues. Other available resources can be found in what she calls the "core economy" - namely, the uncommodified human and "social resources" embedded in the everyday lives of every individual. In contrast, the plea for never-ending economic growth is connected with the concepts of "wants" and "preferences" as conceived in orthodox economics. Those wants are changeable and ultimately insatiable. Instead of orienting ourselves according to our "wants," we must instead orient ourselves to the basic needs that people require in order to participate well in society; here she refers to the Doyal and Gough theory of human need. Given the necessity of connecting societal processes to showing respect for safe planetary boundaries, Coote argues that economic objectives should no longer be derived from the logic of orthodox economics but should instead base themselves on political desiderata, such as the decision not to cross the planetary boundaries. This proposal implies a fundamental change of the current economic paradigm. 
With Apthorpe's article in mind, the following questions can be raised in regard to Coote's new "social settlement." What does her adjectival use here of "social" explain in concepts such as "social policy," "social justice," "social settlement," and "social resources," and what is her conceptual framework? A comparable question concerns the adjectival use of "sustainable." Does an underlying theoretical connection inform her use of "social" and "sustainable," for example in the expression "sustainable social justice"? These questions are relevant also for considering the similarities and differences between "wants" and "needs." Are wants and needs situated on the level of individuals, or are they outcomes of societal processes? Constructing "new social settlements" or "societal settlements" as a basis for overall sustainability depends upon first developing the needed theoretical underpinnings (Van Renswoude et al. 2012).

Dave Elder-Vass's thesis is that defining the economy purely in terms of that which is exchanged in markets and produced for the purpose of such exchange erases "giving" from the economy. To understand the meaning of giving, he refers to Sayer's conception of "moral economy," which looks at factors beyond the mere pursuit of individual self-interest to understand what motivates economic actions. Some of the aspects he considers are emotions, caring, and normative factors (Sayer 2003). ElderVass suggests that the concept of "moral economy" enables us to see that monetary value is only one among various equally important factors that allow societies and individuals to flourish. His article presents an overview of giving - the ideas behind it, the research on it, and the forms it takes in practice. Elder-Vass's presentation of French debates in the twentieth century can serve as an aid for understanding current positions on "giving" as a constitutive aspect of the socio-economic dimension of capitalistic systems. Giving is an important addition to the sister issue of "unpaid labor" as examined in the 1970s. The increasing presence of "giving" is currently expressed in the form of free access to Internet web pages, blog entries, social media posts, and contributions to advice forums. Elder-Vass focuses especially on the creation of free open-source software, which has begun to compete effectively with some of the most successful commodity software. This practice of "giving" goes beyond traditional forms of giving within families or communities. The vast majority of the World Wide Web becomes an immense digital gift, produced by communities of creators all over the world who cooperate to create complex digital content that is then made freely available on the Internet. Because it is free, we cannot measure usage in the monetary terms of conventional economics. Giving is also largely ignored by Marxist political economy.

The challenge that arises from Elder-Vass's argument can be related to Apthorpe's remarks with regard to neoclassical economic writing about growth and poverty: the first should be increased and the other decreased, but the two referents are stored in separate mental "boxes." According to Apthorpe, economic development policy writing tends in practice at any one moment to be focused on only one or the other, growth or poverty. Are the neoclassical, market-driven economy and the moral economy two worlds apart, as Apthorpe suggests, each referring to its own conceptual framework? In both cases - Apthorpe's and Elder-Vass's - how can one connect these worlds if the respective frameworks are different? This challenge is implicitly placed on the agenda by Coote's endeavor to discover the principles of new social settlements 
that do not cross the planetary boundaries. Elder-Vass argues that moral economy may be appreciated as complementary to the social quality approach. His analysis invites us to clarify how to bridge the gap between the capitalistic economy and the moral economy, to consider, in other words, how Coote's "core economy" relates to Sayer's "moral economy."

Bert Helmsing discusses the nature, varieties, and conditions for "social entrepreneurship." This field has received increasing attention because of the growing awareness of the contradictions within the current capitalistic market economy, including the unacceptable inequalities it produces. Helmsing notes how the academic study of social entrepreneurs, entrepreneurship, and enterprise is characterized by an enormous diversity of perspectives and explanations. Some authors suppose social entrepreneurship will replace the capitalistic system. Others argue that it will transform this system. And still others assert that it will play an important role at "the base of the pyramid," where micro and small enterprises provide affordable goods and services that cater to the needs of low-income people. There is also little agreement about the context of social entrepreneurs: they are seen as working within the market, just outside of the market, or in a mixed capacity. According to Helmsing, many authors argue that a fundamental redesign of "social policies" in the Western world through privatization and decentralization - along with the reduction in state subsidies for international development available for non-profit organizations - is an important reason behind current forms of social entrepreneurship. Other authors refer to the failures of the market to address real "social needs" of people, or the inability or refusal of political systems to tackle the related problems. One of his conclusions is that social entrepreneurs engage other stakeholders in the "social domain" and in the base of the pyramid, and the key to their success is building bridges between public, private, and civil economic support.

Helmsing's central theoretical question is (in his words) how "the social" is constituted in "social entrepreneurship." With Apthorpe's article in mind, we can notice a plural adjectival use of "social" in the phrases social policy, social need, social actor, social sector, social entrepreneur, social domain, and social activities. These remain "sightings" because Helmsing's article is not focused on Apthorpe's point but rather on addressing the following question: "[Do] social entrepreneurs privatize what ought to be a collective process and replace the latter with subjective individual visions about how to address social needs or do they engage other stakeholders in public arenas to develop their social value proposition and support for its successful realization?" This question is relevant for all continents. Answering it may require an explicit conceptual framework with which to understand the noun "the social" as a precondition for understanding what is meant by the adjectival application of "social" in all the terms listed above. It may also be a precondition for making adequate scientific judgments about the various interpretations of social entrepreneurship. The same questions arise for the topic of "social innovation," which has much affinity with social entrepreneurship and was a recent subject of discussion in this journal (Oeij et al. 2014).

Feng Hao's article presents the history of the coal industry's pervasive influence upon the American Appalachian mining communities of Harlan County, Kentucky, 
since the beginning of the twentieth century. Hao's ambition is to demonstrate the heuristic meaning of the "social capital" approach in order to deepen this understanding. The case of mining communities has worldwide relevance, including in the context of climate change. Appreciation of the danger of coal mining in relation to the safe limits of Earth's planetary boundaries has grown in recent years (as the Obama Administration's recent policy shift on climate change has demonstrated). Hao concentrates on the relation between "capital and labor" over the past century. Unionization became more and more intense before World War Two and decreased substantially afterward, undermining miners' capacity to defend their working and living conditions. Hao uses a selection of the oral history interviews of miners conducted by Alessandro Portelli between 1983 and 2009, together with "social capital" theory, to look for insights into: (1) processes in the communities of the miners, (2) the nature and change of their affinity and non-affinity with the labor union, and (3) their position regarding the coal industry.

Hao's use of a "social capital approach" as a tool for understanding the interactions of a coal-mining community with key economic factors is of special interest here. $\mathrm{He}$ argues that "social capital is commonly [understood] as capital resources embedded in social relations." Contemporary scholars continue to develop the concept and identify the subcategories of (1) bonding social capital, (2) bridging social capital, and (3) linking social capital. He presents indicators for determining the increase and decrease of the union miners' cohesion and identifies strategies applied by the union to generate "bonding social capital." In the same vein as Apthorpe's analysis, social quality scholars have queried whether analysts and policymakers promoting "social capital" adequately reflect on the adjective "social" and have asked whether the economic concept of "capital" can appropriately be connected with any convenient adjective and then used to analyze the societal whole and processes of transformation. Questions concerning why trust, values, and norms are discussed as "social capital" instead of in terms of social cohesion remain open to debate (Herrmann et al. 2012). The reason could be the lack of an ontological conception of social capital. Thus the term "social capital" itself requires further study to clarify its ontological basis. The well-documented case of the miners in Harlan County can be explored further to address these questions.

In her piece on the methodology for setting the Mexican User Satisfaction Index for Social Programs (MUSI-SP), Odette Lobato-Calleros explains the relevance of a subjective performance assessment of governmental services. The outcomes of such assessments can indicate the extent of trust in the government and provide information for policymakers about the effects of their policies. In Mexico, over 50 million people indicate at least one "social lack" and do not have enough income to satisfy their basic needs. However, social programs have noticeably mitigated poverty and related problems. After explaining the evaluative model used in her research, Lobato-Calleros lays out a methodology for developing a Mexican User Satisfaction Index, using as a basis work done in the United States, Sweden, and Germany.

In terms of its theoretical basis, her study matches the tradition of the subjective "quality of life approach": individuals are asked for information about their personal and subjective interpretation of the effects of particular programs. The study presupposes two vital underlying questions: What is meant by an increase in "quality"? 
What kind of quality do we mean? As argued by Lobato-Calleros, the study is focused on the individual effects and felt effects on individuals of the programs; it is not at this stage focused on the constitution and rationale of the programs compared to other possibilities. The adjectival use of "social" is thus less relevant for this study because of its focus on individual circumstances and not societal circumstances. But further work would explore the political aspects - in this case of the local, provincial, or national political systems in Mexico - and the societal outcomes of these programs as they affect communities, specific networks, and micro-economic relations. Such work would require a theoretical basis that can account for societal processes and the causes of poverty; it would also need to be based on indicators that go beyond the indices applied in MUSI-SP.

Raymond Apthorpe's article about "seventeen sightings of 'social' in economic development policy writing" has been used throughout this editorial as a frame of reference. At the end of the 1990s Apthorpe wrote that the World Bank was advised by one of its own task forces that poverty-oriented projects often depend much more on sociological, cultural, and political factors than do the traditional sectors of World Bank lending, such as physical infrastructure. However, these sociological, cultural, and political factors continued to be neglected, in part (according to Apthorpe) because the World Bank and other funders moved away from project lending when they turned to the economic structural adjustment type of program lending with economy-wide conditionalities. In effect, the World Bank has partly moved away from social analysis and toward market liberalization ideas (Apthorpe 1997). In this earlier study Apthorpe concluded that neoclassical economics models that are dominant in the World Bank and many other organizations have resulted in a treatment of the "social" as a "garbage-bin" of non-economic factors that are used to assign blame. This helps to explain the diverse, scattered, thin, and baffling character of mainstream economic understanding of social factors. Apthorpe's contribution to the present discussion explores what the adjectival use of "social" in "social analysis" really means. His aim is to clarify the "DNA code" in mainstream economic discourses and to argue for "the constitutive power" of a whole "semantic code" (hence the DNA metaphor). With this in mind, he presents an array of neoclassical sightings of the term "social," looking especially at the "policy-performance gap," or "the gap between [an] economic policy [and its] actual performance," as measured in practical outcomes.

Apthorpe aims to deconstruct in order to then reconstruct. This mirrors the original motive for social quality thinking, as presented at the start of this editorial. An intriguing question concerns how far the semantic code and its application are outcomes of linguistic processes and/or of production and reproduction processes and relationships among people. Apthorpe's provocative discussion can contribute to the next stages of assessment of theorizing "the social" in social quality thinking, and also in human security and capability thinking.

\section{References}

Apthorpe, R. 1997. “To Speak 'Social' to 'Economic."' Locality, State and Development, ed. A.H.J. Helmsing and J.P.C. Guimaraes. The Hague: Institute of Social Studies. 
Beck, W., L.J.G. van der Maesen, and A. Walker, eds. 1997. The Social Quality of Europe. The Hague: Kluwer Law International.

Brundtland, G.H. 2012. "Earth Agonistes.” International Herald Tribune. June 19: 8.

Davidson, A. 2015. "A Bailout Bond Buyers Shouldn't Get." International New York Times, 1-2 August, p.12.

Herrmann, P. 2012. "Economic Performance, Social Progress and Social Quality (the Stiglitz, Sen, Fitoussi Report)." International Journal of Social Quality 2 (1): 41-56.

Herrmann, P., L.J.G. van der Maesen, and A. Walker. 2012. "Conceptual Location of social Quality," in Social Quality: From Theory to Indicators, eds. L.J.G. Van der Maesen and A. Walker. Basingstoke: Macmillan, 70-94.

Kougias, K.G. 2014. "Social quality Indicators in Times of Crisis: The Case of Greece.” International Journal of Social Quality 4 (2): 46-69.

Leisering, L. 2013. "Guest Editorial. The 'Social': The Global Career of an Idea." International Journal of Social Quality 3 (2): 1-16.

Oeij, P.R.A., S. Dhondt, and T. Korver. 2011. "Workplace Innovation, Social Innovation, and Social Quality." International Journal of Social Quality 1 (2): 31-50.

Oeij, P.R.A., E. de Vroome, A. Bolland, R. Gründemann and L. van Teefelen. 2014. "Investing in Workplace Innovation Pays Off for SMEs: A Regional Innovation Initiative from the Netherlands." International Journal of Social Quality 4 (2) : 86-106.

Renswoude, J. and L.J.G. van der Maesen. 2012. Development toward Sustainability: The Need for a Comprehensive Conceptual and Methodological Framework for New Politics and Policies. A Social Quality Perspective. Amsterdam and The Hague: International Association on Social Quality. Working paper Series nr. 11 (www.socialquality.org).

Sayer, A. 2003. "(De)commodification, Consumer culture and moral economy." Environment and Planning D: Society and Space 21: 341-357.

UN-Commission for Sustainable Development. 1987. "Our Common Future: the Brundtland Report.” New York: UN, http://w.w.w.un-documents net/ocf-ov.htm 